\title{
Violence and visibility in oil palm and sugarcane conflicts: the case of Polochic Valley, Guatemala
}

Sara Mingorría

Sara Mingorría is a Post-Doc fellow at the Environmental Science and Technology Institute of the Autonomous University of Barcelona (ICTA-UAB). She is a member of the EnvJustice team (www.envjustice.org) and the Laboratory for the Analysis of SocioEcological Systems in a Global World (LASEG). 
2 Violence and visibility in oil palm and sugarcane conflicts:

3 The case of Polochic Valley, Guatemala

4

5 Abstract:

6

7 Over the last two decades, the expansion of oil palm and sugarcane plantations in the

8 Polochic Valley (Guatemala) has exacerbated the historical struggle of Maya-Q'eqchi'

9 peoples for land rights. Based on a mixed methods approach, I examine the dynamics of

10 the conflict between 1998 and 2014, focusing on the visibility, manifestation and

11 intensity of violence and the role of NGOs and peasant organizations in opposition to

12 oil palm and sugarcane plantations. I show that the evolution of the conflict can be

13 explained by changes in the strength of organizations alliances due to tensions, lack of

14 coordination, as well as the fear of state repression and the funding context of these

15 organizations. These results allow me to discuss how violence, the role of these

16 organizations and the dynamics of related events have influenced the visibility of the

17 conflict associated with the expansion of oil palm and sugarcane plantations in the

18 Polochic.

19 Keywords: agrarian and environmental conflicts, flex-crops; human rights, NGOs, 20 peasant organizations 
24 In recent decades, the expansion of large areas of so-called flex-crops ${ }^{1}$, such as oil palm

25 (Elaeis guineensis) and sugarcane (Saccharum officinarum), has led to major social and environmental change in Southeast Asia and Latin America (Borras et al 2011; FAO 2014). This expansion started in 1990 (Asia) and 2000 (Latin America) due to the intensifying demand in the Northern Hemisphere for agrofuels ${ }^{2}$, edible oils, industrial lubricants and cosmetics in the case of oil palm. Sugarcane was similarly sought after in order to produce agrofuels, animal feed or fertilizers. Demand for both flex-crops has also been driven from emerging centers of international capital in the Southern Hemisphere, the so-called BRICS (Brazil, Russia, India, China and South Africa) and some middle-income countries (MICs) (Borras et al 2015). Forecasts suggest that by 2020 the variety and quantity of products fabricated from both crops will only continue to increase (Alonso-Fradejas et al 2016; MacKay et al 2015). Producer countries are thus facilitating the identification, quantification and provision of 'suitable' land for such crops (Borras et al 2013), under the assumption that there are marginal (unpopulated) lands which are apt for cultivation and that these flex-crops can solve manifold energy, climate, economic and financial crises (World Bank 2010).

The expansion of these two crops alone has already led to widespread and major social and environmental changes. In Latin America, they have often prevented local communities from accessing their main livelihoods, as oil palm has been grown on land that communities could use to sow staple crops and native forests, which constitute their

44 principle sources of food, water and building materials (Cardenas 2012; Alonso45 Fradejas 2012). Likewise, both sugarcane and oil palm plantations have reduced soil

\footnotetext{
${ }^{1}$ Flex-crops are commodities that have multiple and interchangeable commercial destinations. For example, palm oil can be sold as food, agrofuel or as an industrial product, while sugarcane can be an agrofuel or food (see Borras et al 2014).

${ }^{2}$ The term 'agrofuel' was coined by the international Via Campesina movement to avoid the use of the prefix 'bio' that refers to life and to stress that the prime materials used for fuels come from agrarian ('agro') sources (Joao Pedro Stedile, MST-La Vía Campesina 6/06/07). In this article, I use agrofuel as a synonym for biofuel.
} 
46 fertility and increased water and air pollution (Goldemberg et al 2008; Martinelli and

47 Filoso 2008). Moreover, social differentiation characterizes oil palm plantations, where

48 the poorest smallholders, the landless and women - often overlapping categories - are

49 oftentimes unable to reap the benefits from cultivation or employment (Alonso-Fradejas

50 2012; Cardenas 2012; Mingorría et al 2014).

51 Many of these negative impacts could be expressed as environmental ${ }^{3}$ and/or agrarian 52 conflicts (Dietz et al 2014; Alonso-Fradejas 2015; Gerber 2011), which may sometimes 53 be made visible by environmental, climatic or agrarian justice movements in 54 transnational campaigns against agrofuels, deforestation or land grabbing (Pye 2010; 55 Brad 2015; Borras et al 2013). However, such impacts may not become visible at a 56 national or international scale, but only at a local scale in certain phases of the conflict 57 (Marin-Burgos 2014). With visibility I refer to conflicts that appear in national and 58 international newspapers and are the object of public demonstrations. In this essay I assess visibility by considering any reference to the conflict in national and international media sources, specifically the printed press. In other cases in Latin America such 61 visibility has conditioned the "success" of struggles against oil palm plantations and the 62 decisions to change strategies of resistance (Marin-Burgos 2014).

63 Recent studies have shown how the visibility of flex-crop conflicts might be influenced 64 by (1) the local population's perception of the benefit or harm caused by plantations 65 (Castellanos-Navarrete and Jansen 2015); (2) the roles and alliances between national 66 and international NGOs and peasant organizations (Pye 2010; Brad 2015); (3) the 67 intensity of the violence at local groups in opposition to the expansion of oil palm 68 plantations; and (4) whether the local population has been dispossessed or not from their 69 land (Maher 2015; Edelman and León 2013; Alonso-Fradejas 2012; Grajales 2011). An

\footnotetext{
${ }^{3}$ This includes conflicts known as ecological, ecological-distributive, socio-environmental or ecological-social and conflicts with environmental content.
} 
example of a conflict that has been visibilized is the accelerated expansion of oil palm in Indonesia, where European and Indonesian environmental and agrarian movements have developed transnational campaigns from shared anti-agrofuel activism. The campaigns highlighted the loss of biodiversity, problems of climate change, dispossession of land and the violation of human rights associated with oil palm plantations (Pye 2010; Grajales 2015; Brad 2015). According to Pye (2010), the antiagrofuels campaign has been successful in: (1) creating transnational debates regarding the main environmental impacts of oil palm plantations and agrofuel production; (2) forging alliances between Indonesian grassroots movements and transnational movements; (3) linking environmental problems with agrarian and human rights issues; and (4) including sustainability criteria on agrofuel production in the European Renewable Energy Directive (EU 2008, article 17).

Recently, studies of oil palm and sugarcane plantation-related conflicts have focused on understanding the role played by agrarian and environmental NGOs at regional (Wolford 2004), national (Brad 2014), and transnational (Pye 2010) scales; or on exploring the conflict from the perspective of local populations (Castellanos-Navarrete and Jansen 2014; Edelmán and León 2013; Alonso-Fradejas 2015). This article contributes to this body of literature by identifying the factors that have influenced the visibility of conflict generated by flex-crops in the Polochic Valley (hereinafter 'Polochic'), Guatemala. In this region, three quarters of the fertile land (more than 10,000 hectares) have been occupied by oil palm and sugarcane plantations since 1998 and 2005 respectively (Alonso-Fradejas et al 2012; Mingorria et al 2014), resulting in recurring and state-acknowledged land conflicts (SAA 2014). However, these conflicts only became internationally known in 2011, after NGOs denounced ongoing violations of land and human rights (OACNUDH 2013). 
95 When I talk about conflicts in this article, I refer to disputes and confrontations, visible 96 or invisible, which occur as a result of flex-crops plantations and/or their expansion.

97 Such disputes can be related to their environmental impacts, potentially resulting in changes in land tenure and resource access relations, and over labor rights and working conditions (Borras et al 2010; Marin-Burgos 2014). In the Polochic, oil palm and sugarcane plantation conflict is manifested through Q'eqchi' groups and a diverse types

101 of social organizations in opposition to the expansion of flex-crops that are controlled 102 by two oligarchic families present in the Polochic. The main arguments in opposition to this expansion are that the growth of flex-crops has generated water pollution, 104 exploitative labor conditions and/or the impossibility of Q'eqchi' population to access 105 land; as well as direct violence, which is understood by Q'eqchi' groups, in similar way 106 as that describe by WHO (1996) individual physical and physiological harm or subtle 107 forms of coercion ${ }^{4}$.

108 The conflict is analyzed by applying a variety of methods a temporal (1998-2014) and multi-scale (local, national and transnational) perspective. Upon identifying the main 110 phases of the conflict, I examine (1) the visibility/invisibility of the conflict and the 111 interactions among Q'eqchi' groups that are in opposition to flex-crops, NGOs, peasant 112 organizations, oligarchic families and government institutions; (2) the manifestation and 113 intensity of the directed violence against local groups in opposition; (3) the roles and 114 interrelations among local, national and transnational NGOs and peasant organizations; 115 and (4) NGOs' perception of the current state of the conflict and future forecasts. These 116 are some of the factors have influenced the evolution of the conflict and explain its 117 multifaceted nature, echoing what has happened in other flex-crops conflicts in Latin 118 America (Marin-Burgos 2014).

\footnotetext{
${ }^{4}$ These arguments come from the minutes of three national peasants meeting against flex-crops in Guatemala (2009 and 2010).
} 
119 In this essay, I consider $\operatorname{NGOs}^{5}$ as the organizations that give support to local

120 communities and act as advocacy groups (Clarck 1991). I treat peasant organizations

121 (CUC and UVOC) separately as I recognize they are based on grassroots memberships.

122 In the text I will use the general term "organizations" when I refer to both of them.

123 The Polochic Valley: sugarcane and oil palm expansion

124 The Polochic Valley is located in northeastern Guatemala, in the departments of Alta

125 Verapaz and Izabal (Figure 1). This agrarian frontier was officially reshaped in 1990,

126 when two protected areas were established: the Sierra de las Minas Reserve $(195,000$

127 hectares) and the Sierra de Santa Cruz (72,000 hectares). These protected areas coexist

128 with indigenous cultivators, the mining industry, traditional coffee estates and cattle

129 ranchers, and more recently sugarcane and oil palm plantations. Eighty-nine per cent of

130 the population is Maya-Q'eqchi' and Poqomchi, found across 220 communities or in

131 the towns of Tamahú, Tucurú, La Tinta, Senahú, Panzós and El Estor. The majority of

132 indigenous inhabitants are landless or land poor, living from swidden (slash and burn)

133 agriculture and complementing their subsistence-based livelihoods with cash-crop

134 production or as seasonal workers (Alonso-Fradejas 2012).

136 According to the Secretariat of Agrarian Affairs (SAA), most recorded conflicts in the 137 Polochic are due to "land occupations", where private ownership is "not respected" by 138 indigenous-peasant communities (SAA 2010). However, for those supporting the 139 Polochic's indigenous-peasant communities, the "occupations" are not the cause of the 140 conflict, but the consequence (Hurtado 2008, Granovsky-Larsen 2013). They are rather 141 their main strategy to access land for subsistence purposes given the unequal

\footnotetext{
${ }^{5}$ I included a variety of NGOs that defined themselves as human right organizations, foundations or research institutes.
} 
142 distribution of arable land and the historical system of labor exploitation that

143 characterizes the history of the Polochic (Castellanos Cambranes 1996, Van Leeuwen

144 2010, Hurtado 2008).

145 The chronicles of land conflict in the Polochic date back to the $16^{\text {th }}$ century, when the

146 Spanish Catholic Church controlled land and local populations through "Indian

147 Villages" ${ }^{6}$ (Hurtado 2008). The commodification of land that started in the $19^{\text {th }}$ century

148 has continued until present, as land has been (re)concentrated to ease the expansion of

149 oil palm and sugarcane plantations (Hurtado 2014). However, part of the Maya-

150 Q'eqchi' people have historically responded to these processes by fleeing wage labor

151 controls, violence and the plunder of their lands, by migrating deeper into Guatemala in

152 search of land to reproduce their livelihoods (Grandia 2006). Most of the Polochic is

153 currently under the control of two oligarchic families, and even the communities that

154 fled to forested areas are now in conflict with company and/or government-controlled

155 protected areas, hydroelectric dams and mining projects (Hurtado 2014).

156 It was after the liberal reforms of the late $19^{\text {th }}$ century that the state granted most of the

157 land in the Polochic as private estates to foreign families and companies, in order to

158 develop an export-oriented economy based on cattle, cotton, bananas and coffee

159 plantations (Hurtado 2008; Grandia 2006). The Maya-Q'eqchi' population that had

160 previously lived in "Indian Villages" was forced to migrate or work on the estates as

161 mozos-colonos or bonded laborers (Hurtado 2008). The patron provided a small piece of

162 land on the estates for bonded laborers to grow their own food and, despite poor wages,

163 forced families to purchase food from his own over-priced shop. Families were thus

164 kept on estates under a flexible debt system (Piedrasanta 1977).

\footnotetext{
${ }^{6}$ The Spanish conquest of the Q'eqchi' region (Alta Verapaz) was, relatively speaking, more peaceful than in the rest of Guatemala (Secaria 1992). However, during the conquest the Spanish church gathered the indigenous population in "Indian Villages" to appropriate their lands and more easily charge them taxes on behalf of the Spanish Crown.
} 
165 The period of greatest violence and visibility of these conflicts on a transnational scale

166 occurred during the 36 years of the Guatemalan civil war and concluded with the

167 signing of the Peace Accords in 1996 (Sanford 2009, Grandin 2004). One of the most

168 violent events happened in Panzós in 1978, when the army massacred fifty-three Maya-

169 Q'eqchi' peasants demanding access to land (CEH 1999). Thousands of people fled

170 from the Polochic during the civil war (Grandia 2006). In the early 2000s the coffee

171 crisis ended the mozos-colonos system (Wagner 2001), breaking the fetter between

172 patrons and the bonded laborers' families. In the wake of this rupture, some families

173 were expelled from the estates without receiving any labor benefits and became landless

174 while others stayed on the land as 'squatters' or became seasonal workers (Hurtado

175 2008, Grandia 2006).

176 Meanwhile, in 1998, the descendants of the German family Maegli set up an oil 177 processing plant. And in 2005 a sugarcane mill called Chabil Utz' aj ('good cane' in the 178 Q'eqchi' language) owned by the Widdman family, was moved from the Southern 179 Pacific region to the Polochic thanks to a two million dollar loan from the Central 180 American Bank for Economic Integration (BCIE). In the Polochic, these two oligarchic 181 families currently control about 5,000 hectares of oil palm and 8,500 hectares of 182 sugarcane plantations, making up one-third of the valley's fertile land (Alonso-Fradejas 183 2012). These families were able to expand their flex-crop plantations throughout the 184 territory either by purchasing land from cattle ranchers or by renting it for a five year 185 period.

186 Part of the Maya-Q'eqchi' population in the Polochic, some landless families, former 187 bonded laborers, plantation workers and households with insecure land tenure are 188 struggling to defend their territory against the expansion of flex-crops through a variety 189 of collective and individual strategies (Alonso-Fradejas 2015). Consequently, in the past 
two decades, the agrarian conflict in the Polochic has escalated around the land dispute

191 between the two families that control the flex-crop production and the groups that claim that same land to grow staple crops (Hurtado 2014; Migorría et al 2014).

193 Over thirty per cent of the agrarian conflicts registered in Guatemala in 2010 were 194 located in the Polochic (SAA 2010), but these were 'invisible' on a national and 195 international scale between the signing of the Peace Accords (1996) and March, (2011), 196 when the state violently evicted the Maya-Q'eqchi' communities 'occupying' some 197 estates in the Polochic, in an action that was highly mediatized (OACNUDH 2013; UDEFEGUA 2011; GIDHS 2013).

Two years later, after national and international demonstrations, some national and international NGOs and a national peasant organization depicted the government's 201 handover of land (partially outside of the Polochic) to some of the previously evicted 202 families as the consequence of successful social mobilization and resistance (Velazquez 203 2014). Subsequently, all international and some national NGOs stopped paying attention to the struggle. However, violent conflict and the crops' expansion continued as the government had failed to deal with the underlying roots of the problem, i.e. unequal land distribution in favor of a few oligarchic families and their agribusiness

207 model. This paper argues that there were multiple factors affecting the exit of 208 organizations and the seeming "success" of the case. I also discuss how structural violence, the role of the state, as well as the different strategies of organizations

210 deployed, have contributed to weaken the resistance against flex-crops in the Polochic 211 and to reveal or silence the conflict. 
214 Data collection through participant observation, semi-structured interviews, discourse

215 analysis and content analysis of the printed press and video documentaries (Figure 2),

216 was triangulated to provide as complete a picture as possible of the conflict period. The

217 analysis begins with the arrival of the oil palm and sugarcane plantations in 1998 and

2182005 respectively, in the municipalities of Panzós and El Estor, and concludes at the

219 end of 2014 when land was finally handed over to some of the evicted families.

220

<Insert FIGURE 2 METHODOLOGY AND OBJECTIVES>

\section{$221 \quad$ Participant observation}

222 From my observations as a researcher and activist during three periods of fieldwork in 223 the Polochic (January 2009-May 2011; January 2012; August 2014) I identified and

224 interviewed members of the NGOs and peasant organizations that were involved in the

225 conflict and opposed the expansion of flex-crops. I pinpointed the events that caused a

226 change in the dynamic of the conflict in terms of its visibility/invisibility, the intensity 227 of the violence exerted against the Q'eqchi' communities and these organization roles 228 and alliances. I evaluated the violence from very low (isolated evictions), to low 229 (injuries, shootings and isolated evictions), high (injuries, shootings, kidnappings, 230 violent and constant evictions) or very high (killings, injuries and shootings 231 concentrated over days). I identified eight organization roles and four types of alliances 232 (Table 1). Subsequently, I analyzed the general positions of Maya-Q'eqchi' community 233 members in relation to the conflict, focusing on those members who participated in 234 national meetings organized by NGOs and a peasant organization to define strategies 235 against flex-crops.

236 During the first period of fieldwork, I attended meetings with organizations and 237 indigenous representatives, where resistance strategies against the expansion of oil palm 
238 and sugarcane plantations in Guatemala were discussed ${ }^{7}$. At the same time, I lived with

239 the Maya-Q'eqchi' population during two active participant research projects ${ }^{8}$ in 2009

240 and 2011, and observed two land occupations in 2010 and the evictions of 2011. During

241 these phases, I analyzed the information obtained from meeting minutes. The

242 occupations and evictions were also recorded in two video-documentaries ${ }^{9}$ where I was

243 part of the executive production, research and interview team. From this experience and

244 the material it generated, I analyzed the arguments against the plantations by Maya-

245 Q'eqchi' people who attended the meetings, as well as the reasons presented by the

246 oligarchic families' to legitimize the evictions.

\section{Semi-structured interviews}

248 During 2014, I conducted a total of 17 interviews with representatives of 9 NGOs and 2

249 peasant organizations (Appendix). I categorized the organizations as local, national or

250 international (and/or donors), depending on their most common scale of operation; and

251 as human rights, development and research and advocacy NGOs and peasant

252 organizations depending on their focus and objectives (Appendix). These interviews

253 served to: (1) validate the phases defined during participant observation; (2) analyze the

254 roles of and interrelations between organizations; and 3) examine the organizations'

255 perceptions of the state of the conflict in the final stage of analysis (2014).

257 My different roles during the research process - as an "external" researcher, peasant organization consultant, human rights evaluator, scholar-activist and witness of the

\footnotetext{
7 This activity included three national (14 communities represented from the Polochic) and three regional (44 communities represented) meetings.

8 'Desarrollo de un marco de evaluación analítico-participativo de las dinámicas socioambientales y de la calidad de vida de las comunidades campesinas del Valle del río Polochic, Guatemala'. IDEAR-CONGCOOP, 2009-2010. Funded by ACCD. 'Mecanismo de respuesta rápida frente a la fuerte subida de los precios de los productos alimenticios en los países en desarrollo'. CUC and FGT, 2010-2011. Funded by Oikos-EU.

${ }^{9}$ The video-documentaries are titled: The evictions in the Polochic Valley 2011 and Aj Ral choch (Sons of the earth), 2012 and were co-produced by IDEAR-CONGCOOP and Caracolproducciones: (see http://caracolproductions.net/).
} 
259 March 2011 evictions - allowed me to gain the trust of the majority of the interviewees

260 and to show my commitment to what was happening on the ground. During the 261 interviews I explained that I have continued researching the conflict in the Polochic for my personal interest, in order to contribute to activism in Guatemala. These elements 263 helped me gather responses that were not accommodating and polite but diverse and 264 critical.

\section{Content analysis}

266 I analyzed the content of three types of documents: written press, human right reports, 267 and the two video-documentaries I was involved in producing. I used these three sources of information because I could not hold face-to-face interviews with all of the stakeholders in the conflict. This was due to the multiplicity of roles I had during my 270 time in Guatemala, which were not aligned with the interests and rationale of the 271 agribusiness families. The analysis was used to (1) validate the defined phases of the 272 conflict through changes in its visibility; (2) identify the phases of greater and lesser 273 visibility of the conflict through the number of news stories published; and (3) describe 274 the changes in the arguments and stances of the oligarchic families and state institutions 275 in relation to the causes of the conflict.

276 On the one hand, I compiled all news in Guatemala's main newspapers (Prensa Libre, 277 El Periódico, Diario de Centro América and Plaza Pública) from 1998 to 2014 and 278 collected the references made on the conflict. I also included news that appeared from 2792005 to 2014 found with the Google search term 'Valle del Polochic', resulting in a 280 total of 160 articles. To analyze this material, I counted the number of news stories and 281 opinion articles in each phase, conducted a lexicometrical analysis using the Iramuteq 282 program to identify the predominant content published during the phases of the conflict and, additionally, analyzed the arguments and positions regarding the causes of the 
conflict mobilized by all actors in each phase of the conflict. Finally, I reviewed the content of 10 reports on human rights violations and press releases by NGOs and peasant organizations that were published between 2000 and 2014. The content analysis involved identifying the strategies and complaints made by these organizations over

288 time.

\section{The evolution of the conflict}

290 The visibility of the conflict from the arrival of oil palm and sugarcane plantations until 2912014 has changed in relation to: the intensity of the violence and the organizations' strategies, roles and alliances. Taking these criteria into consideration, I identified three phases of the conflict: 1) the silenced phase, from the arrival of the plantations in 1998 until the violent eviction of 12 Maya-Q'eqchi' communities in 2011 ; 2) the revealed phase, from the evictions until a year later, in March 2012; and 3) the silencing phase, which began in March 2012 with the Indigenous, Peasant and Popular March and ended in 2014 with the government's handover of land to less than a fifth of the evicted families (Table 2).

\section{Silenced conflict (1998-2011)}

301 Oil palm plantation expansion in the Polochic began silently in 1998. While conflicts 302 were generated by this expansion (Hurtado 2008), they were not framed as such in the 303 printed press ${ }^{10}$. However, the expansion of sugarcane from 2005 was reported in two news articles as an opportunity to develop the local economy (see Dürr 2016 for a

critical perspective). Oil palm and sugarcane underwent their greatest expansion during

\footnotetext{
10 There are many possible reasons why the media did not report land grabbing conflicts and why there were no mobilizations. Although conflict related to land was still present, I think that the media and NGOs were focused on the discussion and promotion of 1996 Peace Accords. Land issues and indigenous rights were approached from this supposedly "post conflict phase". Therefore, NGOs somehow left these conflicts behind and the media did not want to show a possible failure of the Peace Accords.
} 
306 this phase, coming to occupy about 10,000 hectares of the Polochic (Alonso-Fradejas 307 2012, Hurtado 2008). Peasant organization in the region, promoted and supported the 308 collective organization of the former bonded laborers to demand recognition of their

309 land and labor rights, in some cases demanding monetary or land compensation, and in 310 others settlements for their years of unpaid labor on the estates (Granovsky-Larsen 311 2013). From 2000 onwards, these peasant organizations gave their support to the land 312 occupations in Tamahú, Tucurú and Senahú and promoted the creation of a unified front 313 for the 'recovery of the land', organizing both the 'landless' population and the former 314 bonded laborers (Hurtado 2008).

315 National and local NGOs (FGT in 1998, ECAP in 2000 and CONCAD in 2004), 316 appeared in the region to provide psychosocial, technical and organizational support to 317 the Maya-Q'eqchi' communities. In 2005 CONGCOOP started working in the region, 318 while other NGOs connected their work to the expansion of oil palm and sugarcane 319 (Appendix). This date coincides with the transfer of the sugarcane mill from the 320 Southern Pacific region to the Polochic (Figure 3).

322 In 2008, after generating an atmosphere of trust, these organizations discussed with the 323 local population the causes and elements of the conflict in the region. As a results, the 324 NGOs highlighted the psychosocial problems associated with the civil war 325 (Interview\#1); the communities' long and unresolved demands for access to land 326 (Interview\#10); and the socio-economic impacts of the rapid expansion of oil palm and 327 sugarcane plantations and processing plants due to the current national policies that 328 favor business groups and the global economic dynamics of flex-crops' expansion 329 (Alonso-Fradejas 2008, Solano and Solís 2010, Mingorria \& Gamboa 2010). 
330 In 2009, the five NGOs and two-peasant organization mentioned in the silenced phase

331 formed a coalition to stop the advance of oil palm and sugarcane plantations. The 332 coalition included a new research-based NGO, El Observador (Interview\#12) (Figure 333 3). The formation of this coalition meant that the roles of most NGOs shifted from one 334 of community support to facilitating horizontal interaction and joint resistance. To do 335 this, they arranged three national peasant meetings in July 2009, November 2009 and 336 August 2010 as well as two regional meetings in the Polochic, in August and September 3372009 (Figure 3). These meetings aimed at exchanging information between organization 338 and Maya-Q'eqchi' communities, analyzing their different positions in relation to flex339 crops and defining joint strategies against the expansion of flex-crops.

340 During these meetings, the Maya-Q'eqchi' communities also expressed their opposition 341 to flex-crops due to the socio-economic, cultural and environmental damage they 342 generated. They hence defined lines of action aimed at defending their territory and 343 reinforcing the internal cohesion and the networks between Maya-Q'eqchi' 344 communities. To do so, they formed the Council of Q'eqchi' Communities in 345 Resistance, which in 2010 decided to organize the occupation of ten sugarcane 346 plantations in the Polochic. The objective of these occupations was pressure the 347 government into buying the 37 estates owned by the Widdman family that were being 348 auctioned at the time by Guatemala's Industrial National Bank (BI), as a result of the 349 sugarcane mill's bankruptcy and not fulfilling its credit obligations (ElPeriódico August 350 6, 2010, Interview\#12).

351 According to one Maya-Q'eqchi' I spoke with, the occupations also came out of 352 necessity, in order to plant maize, and as a form of resistance. He felt that 353 "sowing[maize] is the struggle and the reason to keep on struggling" (Maya-Q'eqchi' 354 leader in occupied community, 2010). Likewise, during the ceremonies conducted 
355 during the occupations, the spiritual value of maize and land for the Maya-Q'eqchi', 356 compared to the negligent value of sugarcane was starkly apparent: 'All the food collected in our home makes us who we are, but maize is our body. Sugarcane is not of us, we do not sow it. We harvest beans, maize and chili. Corncobs - the black, the yellow - are our body' (Occupied community spiritual guide, 2010).

However, the new wave of occupations was met with violent from the sugarcane company's private security forces (OACNUDH 2013). Given this intensification of the conflict over access to land, the government organized several formal talks involving organizations (Interview\#5). Simultaneously, these organizations negotiated with the government and the BCIE so that the state would buy the recently occupied land 367 (Interview\#12). Despite the high intensity of the violence against the Maya-Q'eqchi', 368 the conflict was not reported in the media, and the protests, negotiations, land occupations and the subsequent repression were silenced on a national and international scale (Table 2).

\section{$371 \quad$ Revealed conflict (2011-2012)}

372 In this phase the Polochic conflict became known nationally and internationally through 373 news articles and opinion pieces published in national and international media (Table 374 2), including a documentary about the evictions broadcasted on national television. This 375 phase covers both the violent conflict and post-eviction phases: the former involving the 376 eviction of 800 families from 12 communities in the Polochic; between the 15 -and 19 of 377 March 2011. The post-eviction phase ran until March 2012 (Figure 4). 
379 For the first time in Guatemala, 14 estates were included in the same court-issued 380 eviction order (of which, 12 were executed). The Widdman family oversaw the 381 evictions, accompanied by employees of the Public Ministry, the state agency in charge 382 of executing court orders, and around 1000 soldiers and the national police (special 383 operations commandos). The oligarchic families pressured the military into burning 384 crops, deciding an exact date and time for the evictions, as to avoid being observed by 385 organization members, and compelled the Ministry of Public Affairs to follow the 386 judge's orders. These power relations were explicitly described in statements by the 387 Widdman family during the eviction recorded in the 2011 documentary titled "Polochic 388 evictions": “The Ministry told me: 'well, this eviction is going to be very difficult,' and I 389 told him: 'for God's sake Minister, execute the order for seizure of the land issued by 390 the competent judge! If not, you are obstructing the law.'”

391 Around 800 families were violently evicted, the National Civil Police killed a peasant, 392 dozens of people were injured and the homes and 1,800 hectares of staple crops were 393 razed or destroyed (OACNUDH 2013, UDEFEGUA 2011). Crop loss meant more than 394 material damage: it was also spiritually and culturally painful. As one Maya Q'eqchi' 395 woman told me in an interview, "it is as if my son was dying, the land is no longer 396 alive". Moreover, for some of the population it was a throwback to the violence of the 397 Civil War, where the military used the burning down of homes and crops as a strategy 398 to prevent the population from returning to their villages (Interview\#12, 9).

399 The presence of NGO and peasant organization members in the area meant that the 400 news of the evictions reached the national and international press. Otherwise, the 401 community did not have the authority or contacts to ensure media coverage of the 402 violence enacted by the Widdman family and the government. In turn, these 403 organizations held press conferences and publicly denounced the evictions, asking that 
404 at the very least the evictions be carried out in a non-violent manner, leaving houses

405 intact and allowing people to harvest their crops. These demands were however 406 unaddressed.

407 In the wake of these violent events, five of the organizations in the coalition remained 408 allied and once again changed their role to protest against the suffering of the families in 409 the Polochic. The coalition condemned the violence, the excessive use of force by the 410 army and the national police and the violation of the right to housing, food and 411 indigenous culture in national and international venues, including the Inter-American 412 Commission on Human Rights (IACHR) ${ }^{11}$ (Figure 4).

413 The Widdman family, however, accused the Maya-Q'eqchi' population of violating the 414 right to private land ownership and the NGOs and peasant organization of subverting 415 the rule of law. During the evictions, that family proclaimed, "laws should be observed! 416 Rule of law!" (Polochic evictions video-documentary 2011), while the government 417 accused organizations of being "radicals that have systematically implemented illegal 418 measures [...] that have affected the rights of other Guatemalans and put governability 419 and the rule of law at great risk" (Presidential announcement 17/03/2015).

420 In June 2011, the IACHR requested Guatemala to take the necessary precautionary 421 measures ${ }^{12}$ to guarantee the life, integrity, food and homes of the twelve evicted 422 communities and to investigate the killing of one peasant during the evictions 423 (OACNUDH 2013). In spite of such request, violence continued and three more 424 peasants were killed a few months later (UDEFEGUA 2011). Some Maya-Q'eqchi'

\footnotetext{
11 The IACHR: the main and autonomous agency of the Organization of American States (OAS) that is responsible for promoting and protecting human rights in the Americas. A summary of the Precautionary Measures can be found at www.cidh.org with Ref: 14 comunidades indígenas Q'echi del Municipio de Panzos MC-121-11, Guatemala. The petitioning NGOs were: the CUC, FGT, ECAP, Human Rights Commission, Rights Action and ULAM (Women's Union).

${ }^{12}$ Precautionary measures: these are measures recommended to states by the IACHR when situations arise where irreparable damage could be caused to people. These include situations of conflict, violence or persecution of the defenders of human rights which if not ceased could lead to an increase in the number of deaths.
} 
425 families tried to immediately occupy again the evicted lands, and the sugarcane

426 company's private security alongside the police responded again with violence (GIDHS

427 2013). Following the IACHR issue of the precautionary measures, the number of

428 organizations in the coalition fell, and only three national organizations continued to

429 condemn the events in alliance with international human rights NGOs. However, these

430 relations also weakened (Figure 4).

$431 \quad$ Silencing conflict (2012-2014)

432 The conflict initially remained visible on a national and transnational scale, with public 433 debates regarding the country's history of agrarian conflict between March 2012 and

434 February 2013. The content of the news items related the evictions in the Polochic to 435 the violence of the Guatemalan civil war and the historic demands of the peasantry such 436 as access to land, agrarian debt forgiveness, a law on Integrated Rural Development, the 437 moratorium on mining licenses and territorial demilitarization (Table 2). However from 438 February 2013-August 2014, the visibility of the conflict began to dwindle, with fewer stories being published in the national press and focusing solely on the relocation of the

440 families (Table 2).

442 This visibility between March 2012 and February 2013 was largely due to the 200-

443 kilometer Indigenous, Peasant and Popular March that took place in early 2012 (from 444 Cobán municipality in Alta Verapaz department, to Guatemala City), and involved 445 NGOs, peasant organizations, trade unions, community representatives and women's 446 organizations. The launch of an international campaign in favor of the evicted families

447 (Crece-Vamos al grano), organized by Intermón Oxfam in February 2013, also 448 increased the visibility of the conflict (Figure 5). These forms of protest emerged in 449 response to the government's non-compliance with the precautionary measures; i.e., the 
450 violence continued, land was not provided, and not enough provisions were given to the 451 evicted families (Interview\#16, 4). The march was led by the CUC, and the FGT, 452 CONGCOOP and representatives of the evicted communities also took part. After the 453 demonstration, the Intermón Oxfam campaign managed to get the conflict onto the 454 public agenda and put pressure on the government by revealing the social and financial 455 plight of the evicted families through protest actions and delivering a petition with over 456100,000 signatures to the government demanding land for the families. This campaign 457 was coordinated in Guatemala exclusively by the CUC, preventing the participation of 458 other national and international organizations. According to Oxfam, an alliance with a 459 single organization made the campaign easier to manage. However, at the same time, 460 this led to the breakdown of alliances with other organizations, and caused the CUC to 461 shift from being a protest group to focus solely on the campaign agenda (Interview\#17) 462 (Figure 5).

463 Following the announcement of the land allocation to the Q'eqchi families in June 464 2013, the conflict's apparent outcome was Janus-faced. On the one hand, success was 465 touted in CUC, CONGCOOP and Intermón Oxfam's reports, social networks and 466 websites. ${ }^{13}$ These sources highlighted various achievements: land allocation for 140 467 families (Velazquez 2014); raising awareness of the global problem of land grabbing 468 through the case of the Polochic; and achieving the international campaign targets. For 469 example, the CUC celebrated the second handover of land with statements on its social 470 networks such as "today our tears are the tears of joy: Victory for the violently evicted 471 families and victory for national and international organizations!" (Facebook CUC 10th 472 August 2014).

13

https://oxfamintermon.s3.amazonaws.com/sites/default/files/documentos/files/memoriaOxfamIntermon2014cas 0.pd f; https://www.facebook.com/Comité-de-Unidad-Campesina-CUC 
473 On the other hand, however, during my fieldwork in August 2014 (the second land

474 reallocation process), I realized that all organizations also perceived the outcomes 475 partially as a failure. The structural problems regarding land access, the expansion of

476 the plantations and the violence directed against the communities had not been resolved

477 (Interview\#4, 11, 8). The conflict was delocalized, with 110 families relocated away 478 from the Polochic to another highly conflictive area of the country (Interview\#2) 479 without meeting minimal subsistence conditions.

480 Moreover, resistance in the Polochic had been weakened because the organizations fled 481 the region and their alliances with Maya-Q'eqchi' communities were debilitated. 482 According to international human rights NGOs, the weakening of such alliances was the 483 result of the difficulties of working in a human rights framework within contexts of 484 systematic violence: "we could spend at least 14 years denouncing the state for not 485 recognizing indigenous rights, however it is important to understand and to know how 486 to do it" (Interview\#8). The effort required to coordinate very different kinds of 487 organizations was also repeated, as was the lack of time, financial resources and fatigue: 488 "It was difficult to coordinate meetings and define actions, we were not all working 489 along the same lines and information was not shared because of distrust" 490 (Interview\#10, Inverview\#9). The direct alliances between Maya-Q'eqchi' communities 491 and national peasant and NGOs also weakened because of the increasing insecurity in 492 the Polochic. "The situation became unsustainable, we received a lot of threats, you 493 could tell that you were being followed ... it was not worth risking my life" 494 (Interview\#1).

\section{Future perspectives of the Polochic conflict}

496 Overall, after analyzing these three phases of the conflict in the Polochic from 1998 to 4972014 , it is evident that the government did not comply with its commitment to distribute 
498 land among indigenous communities or halt the advancement of sugarcane and oil palm

499 plantations. In 2014 the BCIE restructured the Widdman family's outstanding debt, 500 while an oligarchic family from Nicaragua (Grupo Pellas) bought 80 per cent of the 501 company's shares and further invested 40 million dollars in the sugarcane expansion 502 project (Interview\#3). This explains why most organization believed that the situation in 503 the Polochic would only get worse after 2014, with the conflict intensifying and 504 resistance being repressed.

505 The interviews, however, showed that there is no consensus within or among the 506 organizations as to how the conflict in the Polochic should be approached from now on. 507 Some international NGOs believe that the work should consist in putting pressure on 508 the government through institutions such as the World Bank and involving other 509 countries' public opinion (Interview\#17). However, some national peasant 510 organizations and NGOs argued that the strategy should now consist in regionalizing 511 the struggle and to work locally and the overarching objective would be to connect their 512 fight with other struggles, such as the opposition to extractive projects such as mining 513 and major hydroelectric plants.

514 Both proposals, campaigning from abroad and regionalizing resistance, are based on the 515 development of alliances. However, while some national organizations vouch for 516 alliances between international NGOs and their local partners, others aim to coordinate 517 nationally through a United Peasant Front and to develop local alliances through 518 community-based and grassroots organization. In all cases, nonetheless, organizations 519 recognize the need to "overcome the broken ties between organizations" 520 (Interview\#10).

\section{Discussion}


522 The results section analyzed the typologies and visibility of the conflict in the Polochic

523 from a multi-scale and temporal approach. They showed how the interrelations between 524 violence/threat, the role of the state, and the type, strategies and alliances of NGOs and 525 peasant organizations have influenced the visibility and dynamic of the conflict at 526 different scales. The agrarian and human rights conflict was visible at all spatial scales 527 (regional, national and international); the environmental conflict was only visible at 528 peasant meetings.

\section{The role of violence and fear in the Polochic conflict}

530 The expansion of flex-crops in the Polochic has exacerbated the historical land dispute 531 between the Maya-Q'eqchi' communities and the oligarchic families. These 532 communities have struggled for more than 500 years to recover the land they had been 533 dispossessed from: beginning in the colonial era, through to liberal reforms and the 534 development of the agro-export model of cotton, banana, beef and coffee farming 535 (Hurtado 2008; Grandia 2009; Castellanos 1996), until the spread of oil palm and sugarcane plantations in the present day. In this new phase of dispossession, the demand

537 for land has been visible through land occupations in the silenced phase, and protests 538 and campaigns on a national and international scale during the revealed and silencing 539 phases.

540 However, the high level of violence has been the main factor affecting the visibility of

541 the conflict, focusing the debate and the struggle on land access issues and masking the

542 communities' arguments in relation to the environmental and cultural impacts of flex543 crop. It is important to underline that the Polochic is not an isolated case: one of the 544 main historical drivers of rural violence throughout Latin America is the unequal 545 distribution of land (Kay 2001). The latter is also explicitly related to the mechanisms 546 for the expansion of monocultures like oil palm plantations (Alonso-Fradejas 2012; 
547 Grajales 2015; Maher 2015; Edelmán and León 2013). Violence in the Polochic is

548 associated with the mechanisms of expansion and dispossession of land: direct violence

549 recognized by human rights framework (NN.UU 2007). There was violence in all

550 phases of the conflict, from threats, intimidation and the presence of the company's

551 armed private security to killings, kidnappings and violent evictions. This violence had

552 a strong demobilizing effect, as it was applied to a population that had already been

553 heavily repressed (Hurtado 2008). During all phases, violence, and the fear instilled in

554 the minds of the Maya-Q'eqchi' that lived through the Guatemalan civil war,

555 suppressed the local indigenous people's arguments against oil palm and sugarcane

556 plantations. Social fear is a complex collective experience (Pain and Smith 2008) that

557 can be unleashed by isolated events, such as the Panzós Massacre of 1978 (CEH 1999),

558 and by everyday events, like the presence of private security forces, or symbols that

559 bring back memories of the Guatemalan civil war, such as military uniforms, a scorched

560 earth military strategy - burning of homes and crops - to ensure the permanent dispersal

561 of the population, or government announcements outlawing protests.

562 In Guatemala, the threat of violence as a means to generate fear has been systematically

563 used to muffle the peasant struggle for land in the past and in the present (Ibarra 2009).

564 Scott (1986) argues that in contexts of strong repression and violence like those 565 described earlier, the oppressed population develops silent resistance strategies and its 566 oppositional arguments are only shared in secret. Scott (2008) argues that it is only 567 when fear is overcome that visible rebellions and protest actions occur. However, the 568 Maya-Q'eqchi' occupied lands without having overcome their fear, driven instead by 569 the need to feed themselves, by their indigenous identity that attributes a sacred value to 570 the land and maize, and by the historic support of peasant organizations. However, the 
571 state accused such occupiers of exercising violence, invading private property and

572 fueling the conflict.

\section{The role of organizations competing types, strategies and alliances in the conflict}

574 The role and alliances between NGOs, peasant organizations and communities were

575 also key factors for visibilizing the conflict on a national and international scale, in

576 particular through organized claims and protests. These organizations gave financial and

577 methodological support to the land occupations and the organization of peasant

578 meetings during the silenced phase. During this phase, indigenous communities who

579 depended directly on natural resources for subsistence defended their environment from

580 the likely impacts of flex-crops. However, this "environmentalism of the poor"

581 (Martinez-Alier 2002) was not visible on a national or international scale - despite river

582 diversion and contamination, soil degradation (Alonso-Fradejas 2012) -, probably

583 because environmental organizations did not offer sufficient support. These results

584 stand in stark contrast to those found on a transnational scale, where environmental

585 organizations have led the protests against oil palm plantations on the grounds of their

586 impacts to deforestation and biodiversity (Koh \& Wilcove 2007; Venter et al 2008).

587 As the conflict developed, diverse national organizations and international human rights

588 NGOs built alliances, which led to the conflict being depicted as one about rights in the

589 revealed phase, and one about agrarian conflict in the silencing phase. These results

590 coincide with other studies illustrating that both the type of organizations and the

591 alliances between organizations involved in campaigns influence the visibility of a

592 conflict and the arguments of those involved (Brad 2015; Castellanos-Navarrete and

593 Jansen 2015; Pye 2010; Wolford 2004). Alliances between environmental and agrarian

594 organizations have contributed to depict some conflicts as agrarian or environmental 595 struggles on a national and transnational scale, for example through campaigns against 
596 climate change, agrofuels, deforestation and land grabbing (Pye 2010; Brad 2015), and

597 the development or breakdown of alliances between NGOs and peasant organizations 598 and the local population have also sometimes contributed to mask existing conflicts 599 (Wolford 2004; Castellanos-Navarrete and Jansen 2015).

600 In the Polochic, the evolution of the conflict forced peasant organizations and NGOs to 601 change their strategies, and to form new alliances with international NGOs. Similar to 602 other violent agrarian conflicts, the organizations opted to condemn the violation of 603 human rights at the international, rather than the national level (Künnemann and 604 Monsalve 2013, Marin-Burgos 2014). In Guatemala, where the economic power of 605 oligarchic families is historically linked to legislative and judicial power (Casaús-Arzú 606 2010), the human rights framework has not worked in favor of the demands of 607 Polochic's indigenous population, where the right to life, food and housing continues to 608 be denied (OACNUDH 2013). In this case, most of the organizations involved in 609 support of disposed families are not self-identified as a human right organization, 610 however they used the rights framework in different ways, such as claiming the rights to 611 land, to food or to housing for indigenous and peasant communities.

612 According to Monsalve (2013), the functionality of the international human rights 613 framework (UN 1948) depends on the particular context and the extent to which the 614 framework itself has been developed. The results of this research illustrate that a human 615 rights framework does not by itself allow for an effective denunciation of what Galtung 616 (1969) would call "structural violence" or what Nixon (2011) terms "slow violence". 617 The latter refers to the damage to marginalized populations that occurs continuously 618 through time and space, causing almost imperceptible socio-ecological changes (ibid.). 619 In this case, slow violence is the process of dispossessing the Maya-Q'eqchi' population 620 of their resources through contamination process and the persistent denial of historical 
621 rights to land of indigenous communities. This process has provoked, malnutrition,

622 poverty, labor exploitation and the loss of biodiversity (Alonso-Fradejas 2012,

623 Mingorría et al 2014).

624 As opposed to direct violence, this kind of "structural" or "slow violence" is more 625 difficult to denounce in front of the IACHR or national courts since international NGO 626 donors neither finance nor support long processes of denunciation. Difficulties also 627 emerge from the mechanisms and language that would need to be used for such a 628 purpose, requiring human rights "professionals", and the coordination between national 629 and international organizations and local communities. In addition, such "slow 630 violence" is occurring in a falsely named post-conflict context. In the Polochic case, 631 international human rights NGOs only intervened to denounce the incidents of direct 632 violence when there was "proof" - photographs and witnesses - to present to 633 international agencies.

634 The intervention and exit strategies of organizations also caused the conflict to be 635 revealed or silenced. The interference of human rights and international development 636 NGOs elevated the conflict to an international scale, at the same time that their exit or 637 non-intervention silenced the conflict. Financial support was present in all phases of the 638 conflict: from the logistics of the meetings against agro-fuels in the silenced phase, the 639 human rights framework-based complaints and documentary filming in the revealed 640 phase through to the march and the international campaign in the silencing phase. The 641 strategy of the CUC in the silencing phase perhaps influenced by the international 642 funds it had received from Oxfam to develop a more globally visible campaign. Once 643 the campaign finished, the organizations' involvement in the conflict dropped 644 significantly. Although CUC has kept loyal to their own political agenda and principles, 
645 they have been conditioned by a context of shrinking international development

646 cooperation in the last ten years.

647 Moreover, the increased tensions between and within NGOs and peasant organizations

648 due to mistrust, their different strategies and also their fatigue during that transition is

649 likely to influence the Polochic struggle in the short-term future. Such tension and

650 breakdown of alliances on an international scale occurred among the international

651 human rights and national organizations.. Over the course of the conflict, international

652 NGOs pursued specific campaigning actions at international level, while national and

653 local organizations diverged in their strategies depending on the type of organization

654 that they were (development, research or peasant). In other studies, tensions have also

655 been noted between organizations that seek to negotiate and define sustainability criteria

656 with regard to oil palm production and those that are against the expansion of oil palm

657 in and of itself (Borras 2015; Marin-Burgos 2014).

\section{Conclusions}

659 This article has argued that the level of violence and threat, the role of state, and the 660 funding context of NGOs and peasant organization, their strategies and alliances 661 involved have influenced the evolution of the flex-crops' conflict in the Polochic. The 662 support of peasant organizations, many of which had an origin in revolutionary guerrilla 663 groups during Guatemala's civil war, has played a key historical role in the defense of 664 the territory and the struggle for land access (Alonso-Fradejas 2015). Their current role 665 in the conflict over oil palm and sugarcane plantations in the Polochic has also been 666 important, because they have acted as key community supporters and brokers of peasant 667 demands in front of governmental institutions.

668 The analysis of the Polochic conflict has shown that the alliances between NGOs and 669 the rural population have weakened over time, with a decrease in the number of NGOs 
670 present in the region. Tensions and disagreement due to divergent strategies and 671 ideologies have prevented the formation of a solid peasant movement (Bastos and 672 Camus 2003). Direct violence and the threat of violence are key factors behind this 673 weakening, associated with new dynamics in the expansion of flex-crops and the top674 down advocacy in the silenced phased of the conflict by a few international and national 675 NGOs. This has prevented local communities' strategies from taking center stage. As a 676 result of these dynamics, the Polochic conflict is publicly touted as one that is resolved 677 although a concealed, conflict remains.

678 The triangulated methods used in this article have enabled me to observe possible 679 contradictions between the results obtained from participant observation, semi680 structured interviews and content analysis (Nightingale 2015). For example, content 681 analysis showed the conflict to be resolved and successful in the silencing phase, but the 682 interviews illustrated that it was still there and even more complex than in previous 683 years. The results furthermore show the importance of a dynamic and multi-scale 684 perspective in the analysis of conflict, since the visibility and nature of a conflict 685 depends on the scale and moment of analysis and the stakeholders interviewed. Also, 686 the results suggest that no transversal social movement has yet been created in the 687 Polochic to effectively articulate environmental, social, cultural, economic and labor 688 demands against flex-crops, or to address the tension between the sometimes divergent 689 aims and strategies of NGOs, peasant organizations and the local indigenous population.

690 Future studies could conduct a historical analysis of the changes in the language used by 691 Guatemalan agrarian and environmental justice movements to denounce structural 692 violence that emerges in the expansion of flex-crops, and why such changes have 693 occurred, as explored more generally in Central America (see Coklin et al 1995). 
696 The author is most grateful to Esteve Corbera, Gonzalo Gamboa, Berta Martín-López

697 and Joan Martínez-Alier for their very helpful comments on earlier versions of this

698 manuscript and/or copy-editing support. This article contributes to the EnvJustice

699 project at ICTA-UAB. The fieldwork for this paper was partly supported by the

700 European Research Agency under a Marie Curie Career Integration Grant (PCIG09-

701 GA-2011-294234) and by the UAB Fundació Autònoma Solidaria. The author thanks

702 Ana Varela for her support in graphic design and Alexis Rojas and Melissa García-

703 Lamarca and Andrés León for their help with language editing . Any remaining errors

704 are her own.

\section{References:}

706 Alonso-Fradejas, A., Liu, J., Salerno, T., and Xu, Y. 2016. Inquiring into the political 707 economy of oil palm as a global flex crop. Journal of Peasant Studies, 43(1), 141-165.

Alonso-Fradejas, A. 2015. Anything but a story foretold: Multiple politics of resistance to the agrarian extractivist project in Guatemala. Journal of Peasant Studies, 42(3-4), 489-515.

Alonso-Fradejas, A. 2012. Land control-grabbing in Guatemala: the political economy of contemporary agrarian change. Canadian Journal of Development Studies 33(4), 509-528.

Alonso-Fradejas, A., Alonzo, F., and Dürr, J. 2008. Caña de azúcar y palma africana: combustibles para un nuevo ciclo de acumulación y dominio en Guatemala. Guatemala: Magna Terra Editores.

Bastos, S., and Camus, M. 2003. Entre el mecal y el cielo: desarrollo del movimiento maya en Guatemala. FLACSO.

Borras, S.M., Franco, J. C., Isakson, S. R., Levidow, L., and Vervest, P. 2015. The rise of flex crops and commodities: implications for research. Journal of Peasant Studies, 123.

Borras, S.M., Franco, J. C., and Wang, C. 2013. The challenge of global governance of land grabbing: changing international agricultural context and competing political views and strategies. Globalizations, 10(1), 161-179. 
Borras, S.M., Hall, R., Scoones, I., White, B., and Wolford, W. 2011. Towards a better understanding of global land grabbing: an editorial introduction. Journal of Peasant 734 Studies, 38(2), 209-216. 
Gerber, J. F. 2011. Conflicts over industrial tree plantations in the South: Who, how and why? Global Environmental Change, 21(1), 165-176.

Goldemberg, J., Coelho, S. T., and Guardabassi, P. 2008. The sustainability of ethanol production from sugarcane. Energy policy, 36(6), 2086-2097.

Grajales, J. 2015. Land grabbing, legal contention and institutional change in Colombia. Journal of Peasant Studies, 42(3-4), 541-560.

Grajales, J. 2011. The rifle and the title: paramilitary violence, land grab and land control in Colombia. Journal of Peasant Studies, 38(4), 771-792.

Grandia, L. 2009. Raw hides: Hegemony and cattle in Guatemala's northern lowlands. Geoforum, 40(5), 720-731

Grandia, L. 2006. Land dispossession and enduring inequity for the Q'eqchi' Maya in the Guatemalan and Belizean frontier colonization process reactions. Berkeley, CA: University of California-Berkeley

Grandin, G. 2004, The Last Colonial Massacre: Latin America in the Cold War. Chicago: University of Chicago Press.

Granovsky-Larsen, S. 2013. Between the bullet and the bank: agrarian conflict and access to land in neoliberal Guatemala. Journal of Peasant Studies, 40(2), 325-350.

Hurtado, L. 2008. Dinámicas agrarias y reproducción campesina en la globalización. El caso de Alta Verapaz, 1970-2007. Guatemala: F\&G.

Hurtado, L. 2014. La histórica disputa de las tierras del valle del Polochic. Estudio sobre la propiedad agraria. Guatemala: Serviprensa.

Kay, C. 2001 Reflections on rural violence in Latin America, Third World Quarterly, 22:5, 741-775.

Koh, L. P., and Wilcove, D. S. 2008. Is oil palm agriculture really destroying tropical biodiversity? Conservation letters, 1(2), 60-64.

Künnemann, R., and Monsalve, S. 2013. International human rights and governing land grabbing: a view from global civil society. Globalizations, 10(1), 123-139.

Maher, D. 2015. Rooted in violence: Civil war, international trade and the expansion of palm oil in Colombia. New Political Economy 20 (2): 299-330.

Marin-Burgos, V. 2014. Access, power and justice in commodity frontiers. The political ecology of access to land and palm oil expansion in Colombia. PhD diss., University of Twente, Netherlands.

Martinelli, L. A., and Filoso, S. 2008. Expansion of sugarcane ethanol production in Brazil: environmental and social challenges. Ecological Applications, 18(4), 885-898. 
Martinez-Alier J., 2002. The Environmentalism of the Poor: A Study of Ecological

Conflicts and Valuation. Edward Elgar, Cheltenham.

McCarthy, J. F. 2010. Processes of inclusion and adverse incorporation: oil palm and

Mingorría, S., Gamboa, G., Martín-López, B., and Corbera, E. 2014. The oil palm Guatemala. Environment, Development and Sustainability, 16(4), 841-871.

Monsalve, S., 2013. The human rights framework in contemporary agrarian struggles. Journal of Peasant Studies, 40(1), 239-290.

Munck. G. 1992. Review article. Journal of development Studies, 29 (1): 170-181.

Nightingale, A.J. 2015. Adaptive scholarship and situated knowledges? Hybrid methodologies and plural epistemologies in climate change adaptation research. Area, 48(1), 41-47.

Nixon, R. 2011. Slow Violence and the Environmentalism of the Poor. Harvard University Press.

OACNUDH- Oficina del Alto Comisionado de Naciones Unidas-2013. Una mirada a la problemática agraria y a la defensa de los derechos humanos de las comunidades q'eqchi's, Guatemala.

Pain, R., and Smith, S. 2008. Fear: critical geopolitics and everyday life. Ashgate Publishing, Ltd.

Piedrasanta, A. R. 1977. Introducción a los problemas económicos de Guatemala. Universdidad de San Carlos de Guatemala.

Pye, O. 2010. The biofuel connection-transnational activism and the palm oil boom. Journal of Peasant Studies, 37(4), 851-874.

Sanford, V. 2009. La masacre de Panzós: etnicidad, tierra y violencia en Guatemala. F\&G.

SAA. Secretariat of Agrarian Affairs. 2010. http://portal.saa.gob.gt/. Access on September 12, 2014.

SAA. Secretariat of Agrarian Affairs. 2014. http://portal.saa.gob.gt/.. Access on September 12, 2014.

Scott, J. C. 2008. Weapons of the weak: Everyday forms of peasant resistance. Yale university Press.

Scott, J. (1986). Everyday forms of peasant resistance. The Journal of Peasant Studies, 13(2), 5-35. 
883 Solano, L, Solís., F. 2010. La palma africana: agronegocio que se expande. El 884 Observador 28-29.

UDEFEGUA. 2011. La violación de los derechos humanos en el Valle del Polochic,

UN- United Nations-1948. Universal Declaration of Human Rights. General Assembly, resolution 217 A (III), Paris. Accesed on September 2015 http://www.un.org/en/documents/udhr/.

894 conflict Guatemala. Journal of Latin American Studies, 42(01), 91-119.

Velázquez., H. Guatemala: reubicación de familias de agricultores en el valle del 897 Polochic. Diez propuestas para la acción política de tierras y territorios en América 898 Latina: análisis a partir de casos exitosos de incidencia exitosa en la región. Centro 899 Peruano de Ciencias Sociales-CEPES-

Venter, O., Meijaard, E., \& Wilson, K. (2008). Strategies and alliances needed to protect forest from palm-oil industry. Nature, 451(7174), 16-16.

Wagner, R. 2001. Historia del café de Guatemala. Guatemala: Villegas Asociados.

906 Wolford, W. 2004. Of land and labor: agrarian reform on the sugarcane plantations of 907 Northeast Brazil. Latin American Perspectives, 31(2), 147-170. Equitable Results? Washington DC. 913 World Health Organization, Document WHO/EHA/SPI.POA.2. 
APPENDIX. - NGOs and peasant organizations classification by impact scale and focus

\begin{tabular}{|c|c|c|c|c|}
\hline $\begin{array}{l}\text { NGOs and } \\
\text { other } \\
\text { organizations }\end{array}$ & $\begin{array}{l}\text { Meaning of acronym and work areas related } \\
\text { with the Polochic case }\end{array}$ & Interviewees & $\begin{array}{l}\text { Operational scale of } \\
\text { action }\end{array}$ & Focus on \\
\hline ECAP & $\begin{array}{l}\text { Equipo de Estudios Comunitarios y Acción } \\
\text { psicosocial (Community Study and Psychosocial } \\
\text { Action Team) } \\
\text { Provides psychosocial support to the victims of the } \\
\text { Guatemalan Civil War }\end{array}$ & $\begin{array}{l}\text { Former specialist } \\
\text { member of the } \\
\text { organization }\end{array}$ & National & Development \\
\hline UVOC & $\begin{array}{l}\text { Unión Verapacense de Organizaciones } \\
\text { Campesinas (Verapaz Union of Peasant } \\
\text { Organizations) } \\
\text { Campaigns for integrated rural development } \\
\text { through legal and organizational guidance with } \\
\text { access to and use, tenancy and ownership of land, } \\
\text { labor rights, community and productive } \\
\text { development. Pressures for, negotiates and } \\
\text { proposes laws before Congress. }\end{array}$ & $\begin{array}{l}\text { One representative } \\
\text { and one field } \\
\text { specialist }\end{array}$ & National & Peasant \\
\hline $\mathrm{CUC}$ & $\begin{array}{l}\text { Comité de Unidad Campesina (Committee for } \\
\text { Peasant Unity) } \\
\text { Campaigns for integrated rural development } \\
\text { through legal and organizational guidance with } \\
\text { access to and use, tenancy and ownership of land, } \\
\text { labor rights, community and productive } \\
\text { development. Pressures for, negotiates and } \\
\text { proposes laws before Congress. }\end{array}$ & $\begin{array}{l}\text { One representative } \\
\text { and two field } \\
\text { specialists }\end{array}$ & National & Peasant \\
\hline
\end{tabular}




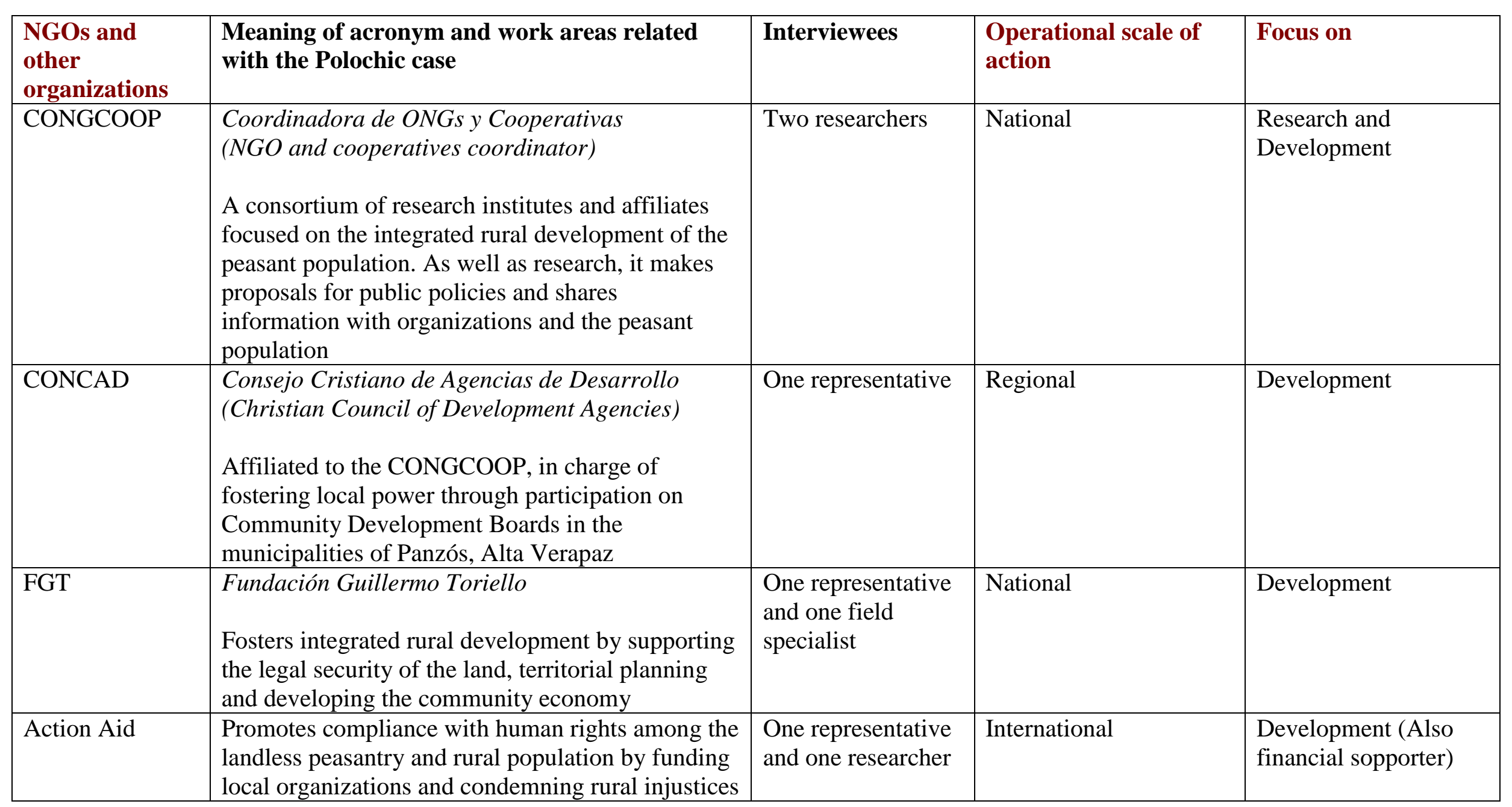




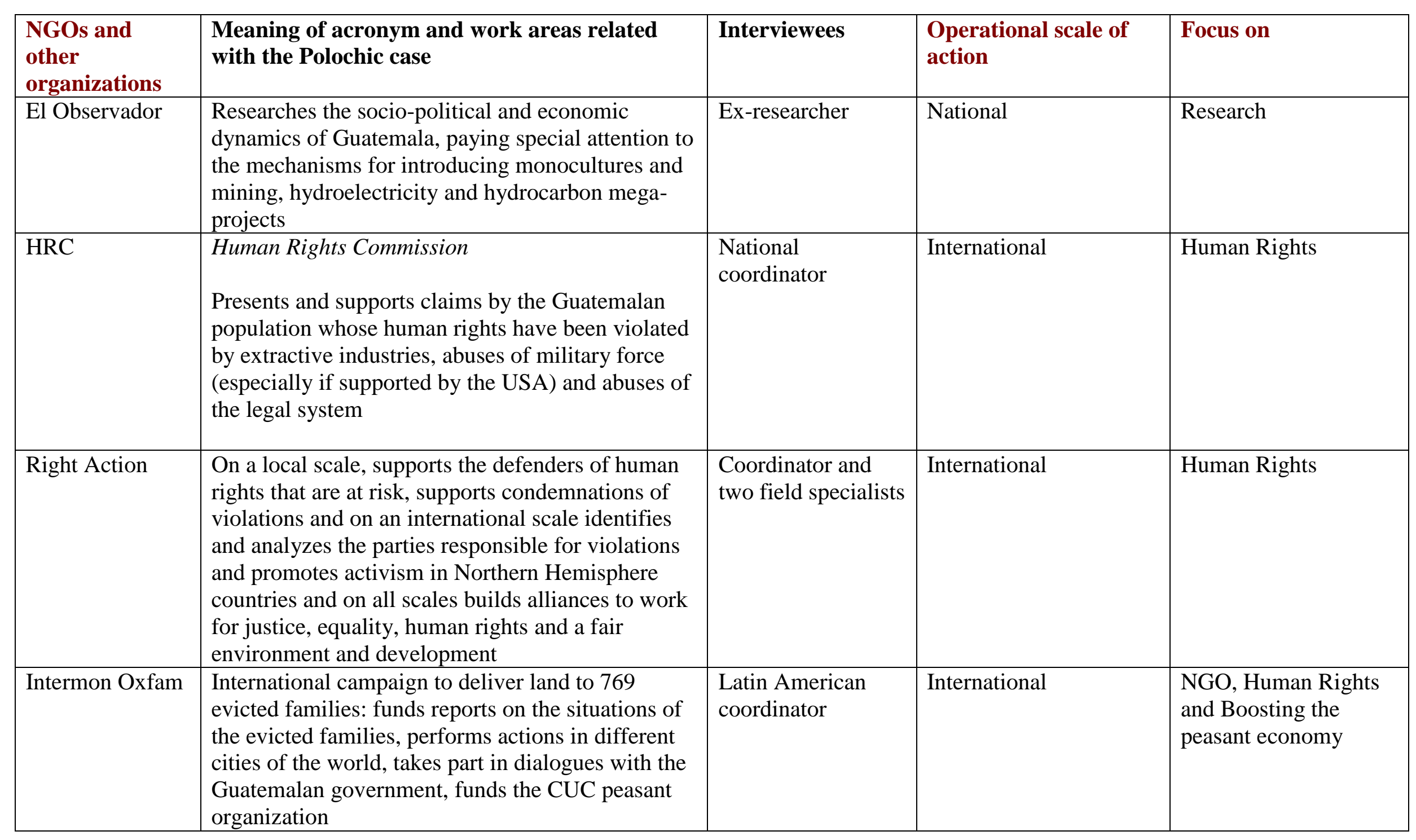


Table 1. - Definitions of the main roles attached to NGOs during the Polochic conflict

\begin{tabular}{|l|l|}
\hline Role & Definition \\
\hline Counterpart/partner & $\begin{array}{l}\text { Serve as the voice and image that responds to } \\
\text { the agenda and requirements of another } \\
\text { organization that has the resources }\end{array}$ \\
\hline Denunciation & $\begin{array}{l}\text { Obtain information about the origin of the } \\
\text { conflict and hold press conferences, issue } \\
\text { press releases or transfer information to other } \\
\text { organizations that influence international } \\
\text { agencies. } \\
\text { Present the information to international } \\
\text { agencies }\end{array}$ \\
\hline Facilitation & $\begin{array}{l}\text { Support collective strategy-defining } \\
\text { processes: provide information, coordinate } \\
\text { joint events, fund meetings, offer a collective } \\
\text { identity to the peasantry }\end{array}$ \\
\hline Mobilization of resources & $\begin{array}{l}\text { Fundraise from local and foreign sources to } \\
\text { organize major campaigns and large-scale } \\
\text { mobilizations }\end{array}$ \\
\hline Negotiation with the State & $\begin{array}{l}\text { Present arguments to state institutions and } \\
\text { discuss and agree to measures }\end{array}$ \\
\hline Protest & $\begin{array}{l}\text { Organize and coordinate protests such as } \\
\text { demonstrations and strikes }\end{array}$ \\
\hline Research & Conduct studies of the causes of the conflict \\
\hline Support & $\begin{array}{l}\text { Support communities with their everyday } \\
\text { needs: legal, organizational and technical } \\
\text { guidance }\end{array}$ \\
\hline Type of alliances & Four or more networked organizations \\
\hline Coalition & $\begin{array}{l}\text { Less than four networked organizations and a } \\
\text { trust relationship }\end{array}$ \\
\hline Strong alliances & $\begin{array}{l}\text { Less than four networked organizations but } \\
\text { lack of trust relationship }\end{array}$ \\
\hline Weak alliances & \\
\hline
\end{tabular}


Table 2. - Characterization of the phases of the conflict: Intensity of the conflict, narratives of new stories, roles and alliances of NGOs.

\begin{tabular}{|c|c|c|c|c|}
\hline & $\begin{array}{c}\text { Silenced } \\
(1998-2011) \\
\end{array}$ & $\begin{array}{c}\text { Revealed } \\
(2011-2012)\end{array}$ & \multicolumn{2}{|c|}{$\begin{array}{l}\text { Silencing } \\
(2012-2014)\end{array}$} \\
\hline Visibility & Latent & Visible & Visible & Latent \\
\hline $\begin{array}{l}\text { Scale of visibility (number } \\
\text { of news items) }\end{array}$ & $\begin{array}{l}\text { Regional } \\
\text { (2) }\end{array}$ & $\begin{array}{l}\text { National and transnational } \\
\qquad(59)\end{array}$ & $\begin{array}{l}\text { National and } \\
\text { transnational } \\
\text { (29) }\end{array}$ & $\begin{array}{l}\text { Regional } \\
\text { (16) }\end{array}$ \\
\hline Intensity of violence & High & Very high & \multicolumn{2}{|c|}{ High } \\
\hline $\begin{array}{l}\text { Type of NGOs by } \\
\text { operational scale of action } \\
\text { (number of organizations) }\end{array}$ & $\begin{array}{c}\text { Local (1) } \\
\text { National (6) } \\
\text { Transnational (1) }\end{array}$ & $\begin{array}{c}\text { Local (1) } \\
\text { National (5) } \\
\text { Transnational (3) }\end{array}$ & $\begin{array}{c}\text { Local (1) } \\
\text { National (4) } \\
\text { Transnational (1) }\end{array}$ & $\begin{array}{c}\text { Local (1) } \\
\text { National (3) } \\
\text { Transnational (1) }\end{array}$ \\
\hline
\end{tabular}




\begin{tabular}{|c|c|c|c|c|c|}
\hline \multirow[b]{2}{*}{$\begin{array}{l}\text { Roles (organizations' } \\
\text { acronyms) }\end{array}$} & \multicolumn{2}{|c|}{$\begin{array}{c}\text { Silenced } \\
(1998-2011)\end{array}$} & \multirow{2}{*}{ 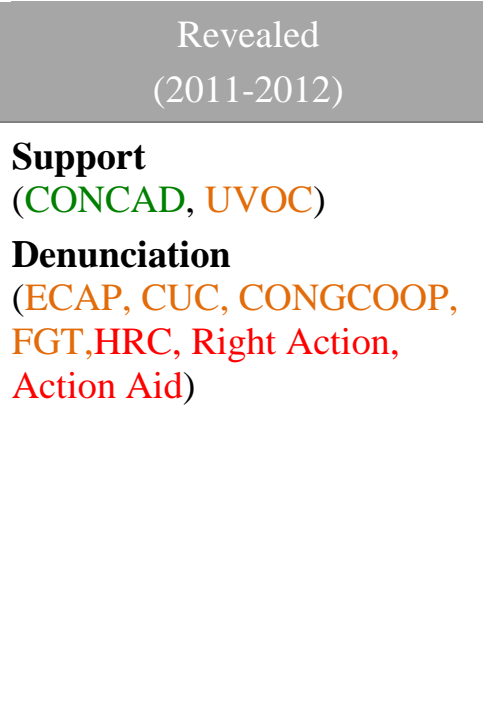 } & \multicolumn{2}{|c|}{$\begin{array}{l}\text { Silencing } \\
(2012-2014)\end{array}$} \\
\hline & $\begin{array}{l}\text { Support } \\
\text { (COCAD, UVOC, } \\
\text { ECAP, CUC, } \\
\text { CONGCOOP, FGT) } \\
\text { Research } \\
\text { (CONGCOOP,Actio } \\
\text { n Aid) }\end{array}$ & $\begin{array}{l}\text { Support } \\
\text { (UVOC) } \\
\text { Facilitation } \\
\text { (COCAD, } \\
\text { ECAP,CUC, } \\
\text { CONGCOOP, El } \\
\text { Observador, } \\
\text { FGT, Action } \\
\text { Aid) } \\
\text { Negotiation } \\
\text { (CUC, FGT, } \\
\text { Action Aid) }\end{array}$ & & $\begin{array}{l}\text { Support } \\
\text { (CONCAD, UVOC) } \\
\text { Protest } \\
\text { (CUC, FGT) } \\
\text { Negotiation } \\
\text { (CUC, CONGCOOP, } \\
\text { FGT) } \\
\text { Mobilization of } \\
\text { Resources (Intermon } \\
\text { Oxfam) }\end{array}$ & $\begin{array}{l}\text { Support } \\
\text { (CONCAD, UVOC, } \\
\text { FGT) } \\
\text { Research } \\
\text { (Action Aid) } \\
\text { Negotiation } \\
\text { (CUC) } \\
\text { Mobilization of } \\
\text { Resources (Intemon } \\
\text { Oxfam) } \\
\text { Counterpart } \\
\text { (CUC) }\end{array}$ \\
\hline $\begin{array}{l}\text { Alliances (number of } \\
\text { organizations) }\end{array}$ & - & $\begin{array}{l}\text { Strong coalition } \\
\text { (7) }\end{array}$ & $\begin{array}{l}\text { Strong coalition (5) and weak } \\
\text { alliances ((5) and (2)) }\end{array}$ & $\begin{array}{l}\text { Weak alliances }((1) \text { and } \\
(3))\end{array}$ & $\begin{array}{l}\text { Weak alliance ((1) and } \\
(1)) \\
\text { Weak alliance ((1) and } \\
(1))\end{array}$ \\
\hline
\end{tabular}

The principal scale of action is regional

The principal scale of action is national

The principal scale of action is international 


\section{Figure Captions}

Figure 1. Case study area: The Polochic Valley

Source: Mingorría et al (2014). The red area represents the oil palm plantations, the yellow area represents the sugar cane plantations and the green area demarcates the Sierra de las Minas and Bocas del Polochic protected areas.

Figure 2. Methodological strategy and research objectives

Figure 3. Conflict dynamics during the Silenced phase: NGOs alliances and main events

Figure 4. Conflict dynamics during the Revealed phase: NGOs alliances and main events

Figure 5. Conflict dynamics during the Silencing phase: NGOs alliances and main events 


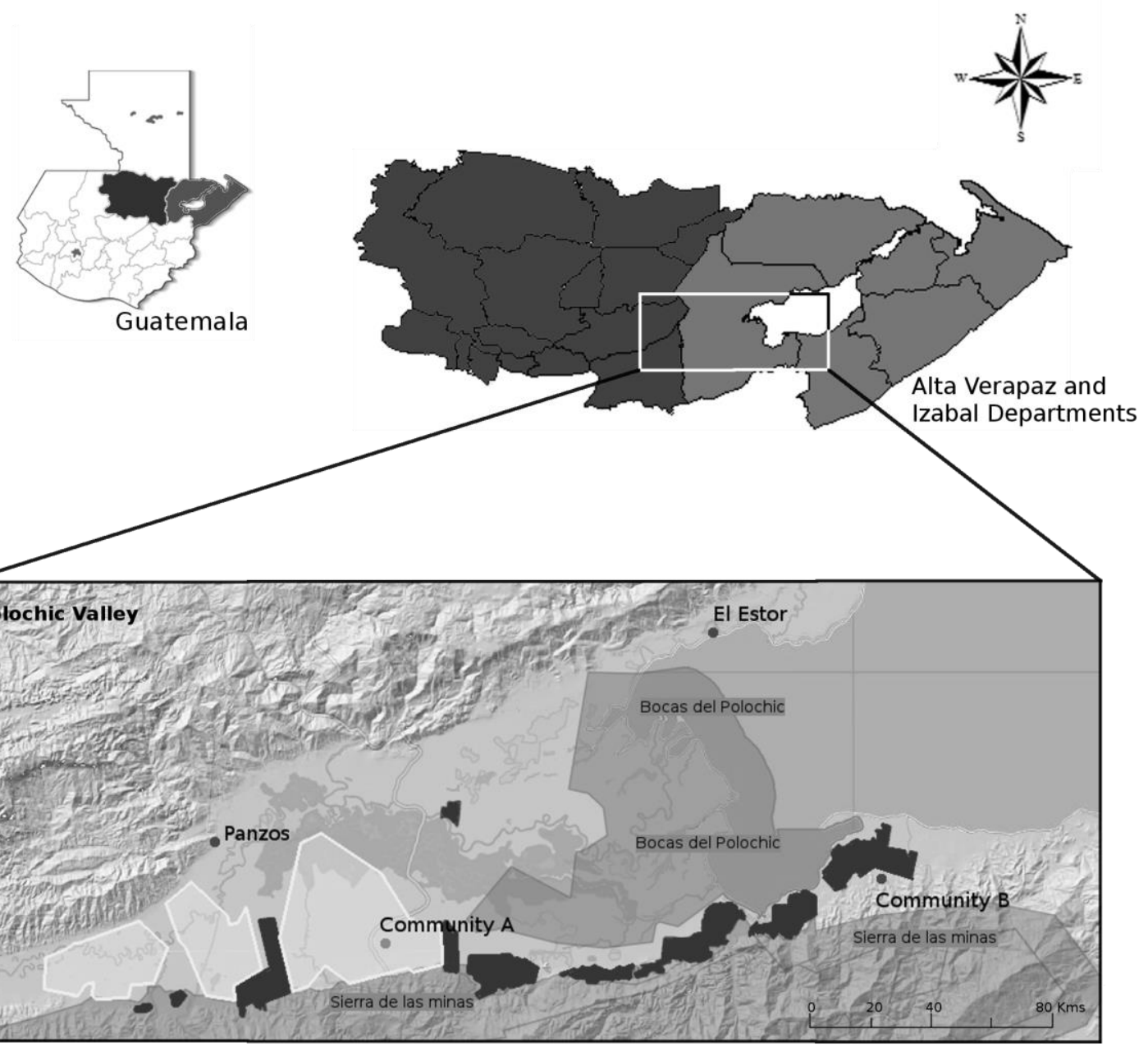

Figure 1. Case study area: The Polochic Valley.

Source: Own elaboration based on information from Geographic Information System of Ministry of Agriculture, Livestock and Food of Guatemala (SIG-MAGA); and observations during the fieldwork. The black polygons represents the oil palm plantations, the white polygons represents the sugar cane plantations and the grey polygons demarcates the Sierra de las Minas and Bocas del Polochic protected areas. 
Obj: Understand the environmental and agrarian conflicts generated by the development of oil palm and sugar cane from a multi-scale and temporal perspective.

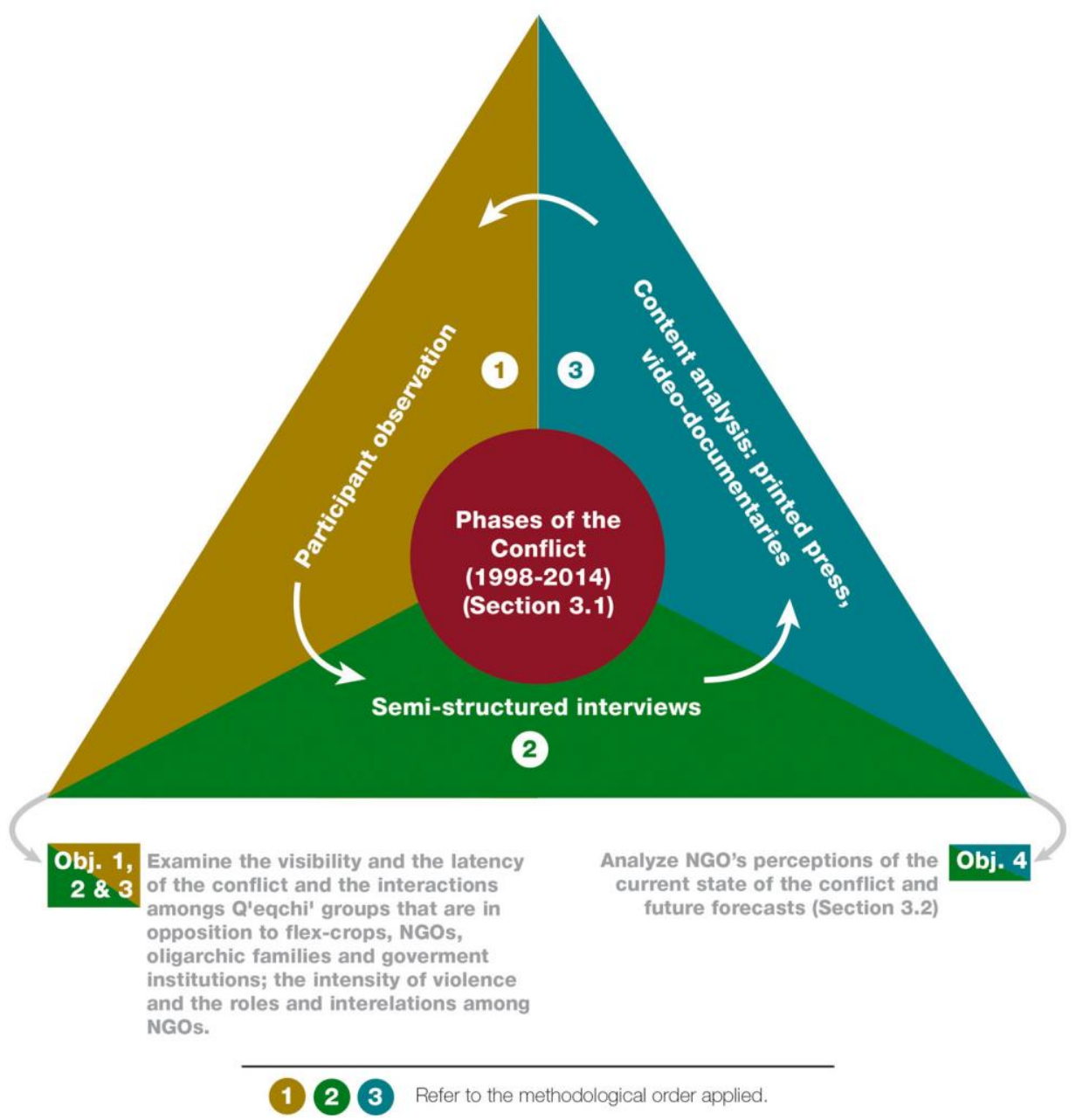

Figure 2. Methodological strategy and research objectives. 


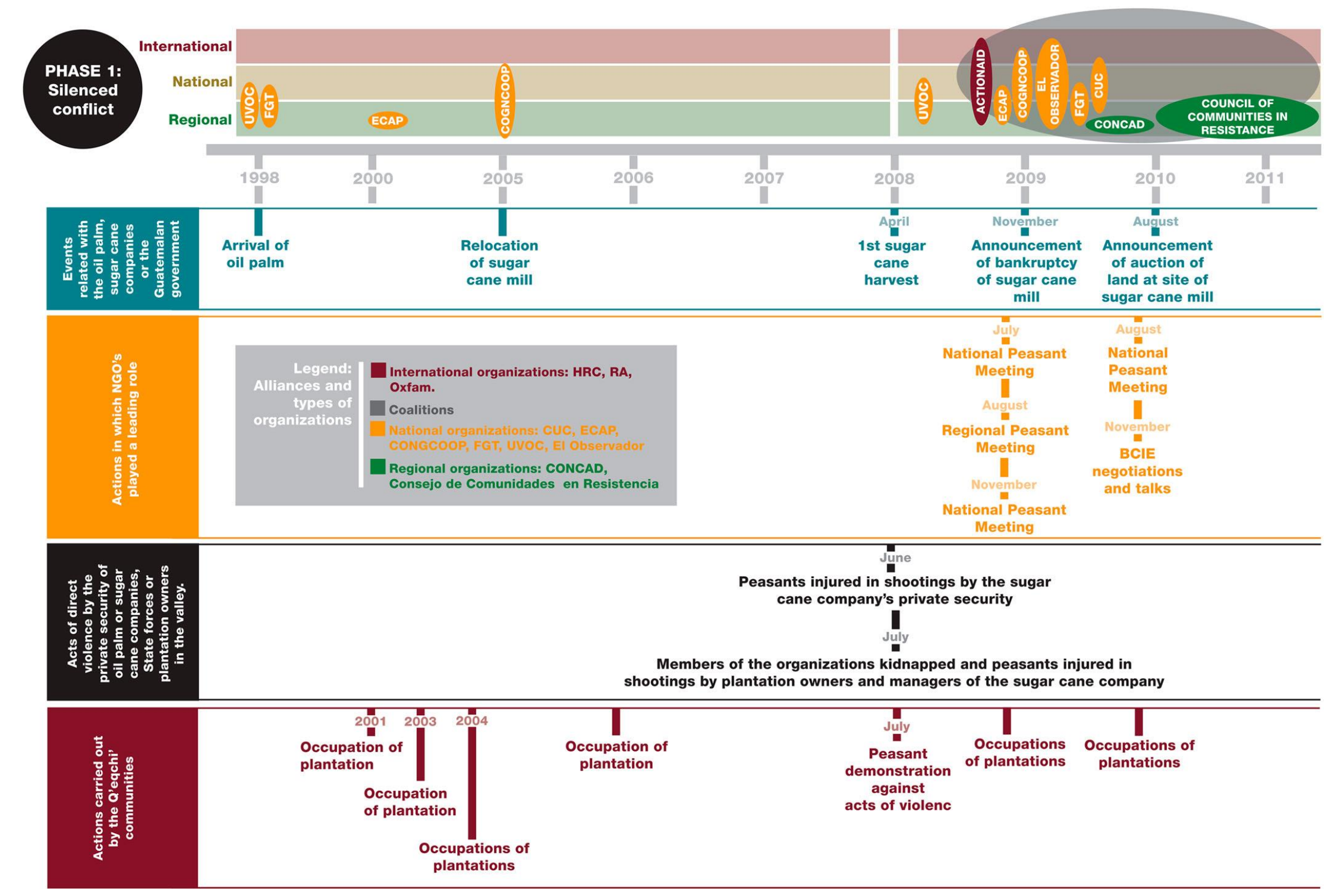

Figure 3. Conflict dynamics during the Silenced phase: Non-Governmental Organizations (NGOs) alliances and main events. 


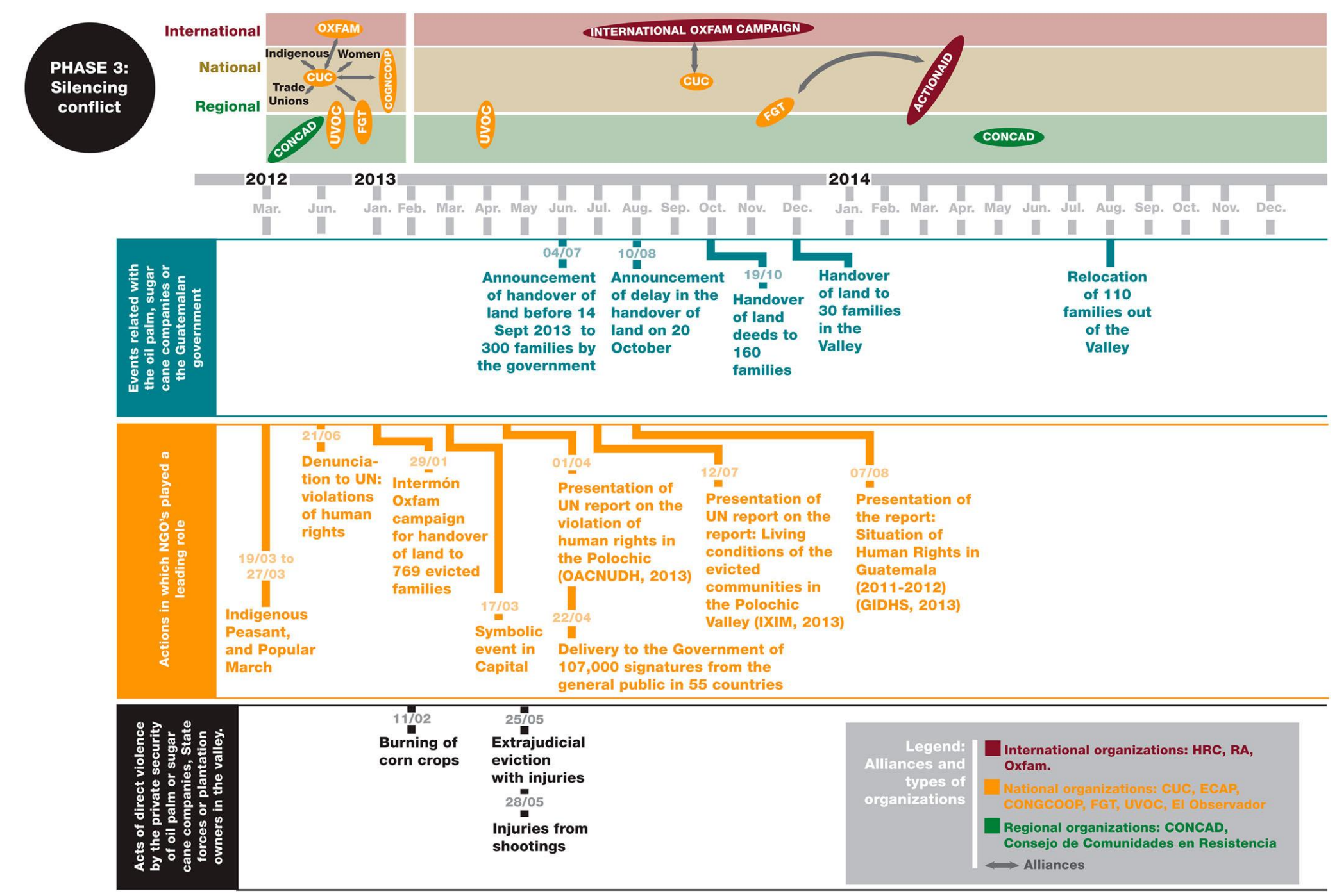

Figure 4. Conflict dynamics during the Revealed phase: Non-Governmental Organizations (NGOs) alliances and main events. 


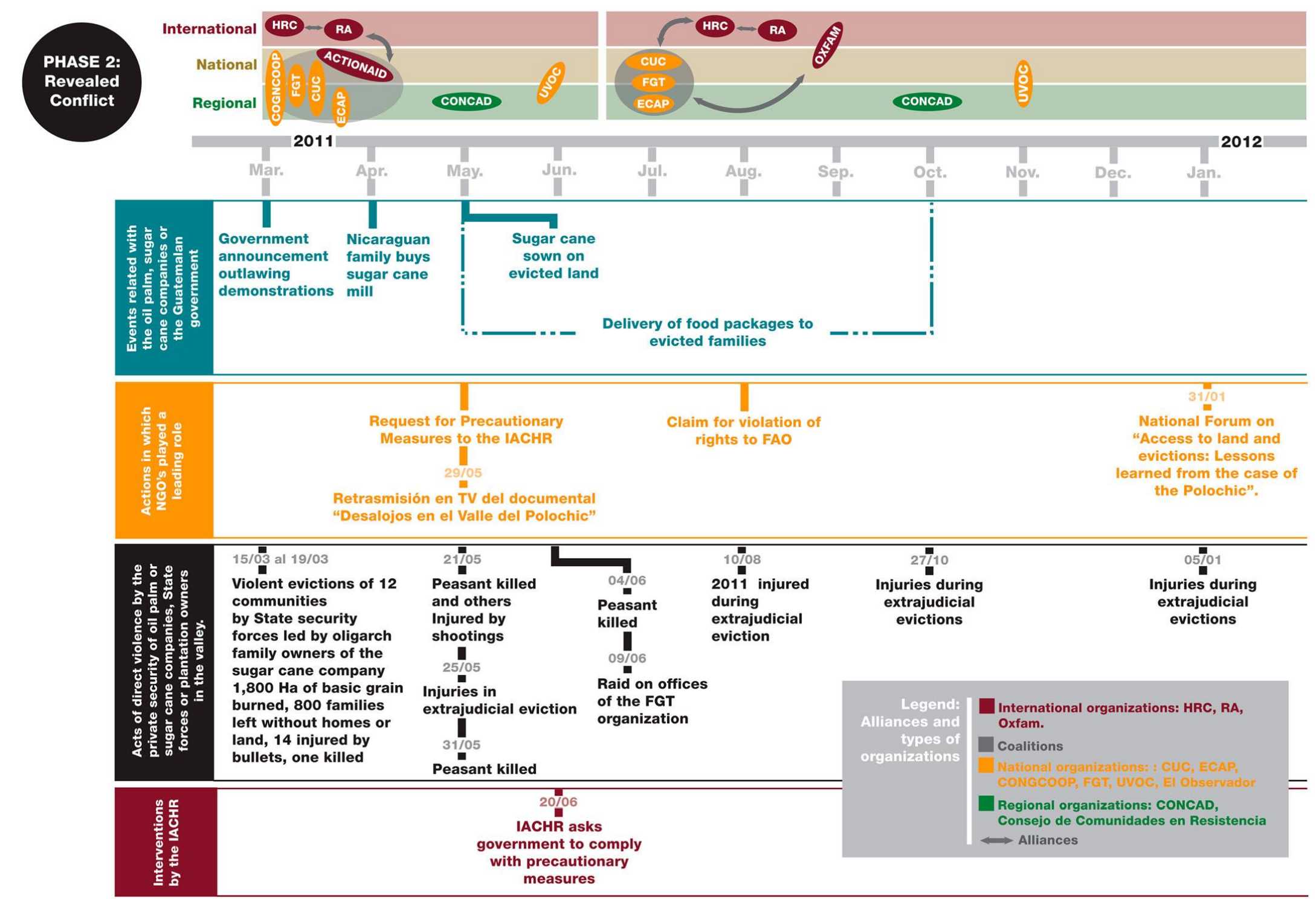

Figure 5. Conflict dynamics during the Silencing phase: Non-Governmental Organizations (NGOs) alliances and main events. 